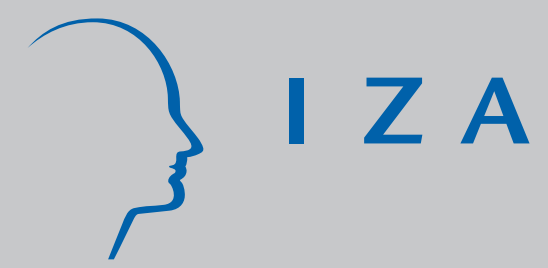

IZA DP No. 8660

Ageing in a Long-term Regeneration Neighbourhood:

A Disruptive Experience or Successful Ageing in Place?

Reinout Kleinhans

Lex Veldboer

Sylvia Jansen

Maarten van Ham

November 2014 


\title{
Ageing in a Long-term Regeneration Neighbourhood: A Disruptive Experience or Successful Ageing in Place?
}

\author{
Reinout Kleinhans
}

Delft University of Technology

Lex Veldboer

University of Amsterdam

Sylvia Jansen

Delft University of Technology

Maarten van Ham

Delft University of Technology and IZA

\author{
Discussion Paper No. 8660 \\ November 2014
}

\author{
IZA \\ P.O. Box 7240 \\ 53072 Bonn \\ Germany \\ Phone: +49-228-3894-0 \\ Fax: +49-228-3894-180 \\ E-mail: iza@iza.org
}

Any opinions expressed here are those of the author(s) and not those of IZA. Research published in this series may include views on policy, but the institute itself takes no institutional policy positions. The IZA research network is committed to the IZA Guiding Principles of Research Integrity.

The Institute for the Study of Labor (IZA) in Bonn is a local and virtual international research center and a place of communication between science, politics and business. IZA is an independent nonprofit organization supported by Deutsche Post Foundation. The center is associated with the University of Bonn and offers a stimulating research environment through its international network, workshops and conferences, data service, project support, research visits and doctoral program. IZA engages in (i) original and internationally competitive research in all fields of labor economics, (ii) development of policy concepts, and (iii) dissemination of research results and concepts to the interested public.

IZA Discussion Papers often represent preliminary work and are circulated to encourage discussion. Citation of such a paper should account for its provisional character. A revised version may be available directly from the author. 


\section{ABSTRACT}

\section{Ageing in a Long-term Regeneration Neighbourhood: A Disruptive Experience or Successful Ageing in Place?}

The aging population of European cities raises enormous challenges with regard to employment, pensions, health care and other age-related services. The housing preferences of the aging population are changing rapidly where more and more people want to live independent lives for as long as possible. At the same time governments need to reduce the costs of expensive institutionalized care. A precondition for 'ageing in place' is that elderly people perceive their neighbourhoods as familiar and safe places. In the Netherlands, many neighbourhoods with a rapidly ageing population have been subject to urban regeneration policies. Hence, an important question is to what extent these policies affect the housing situation, social support networks and socioeconomic position of elderly people, because these factors strongly assist the ability of elderly people to live independently. We answer this question through the analysis of a small but unique panel data set with 2007 and 2012 measurements from Hoogvliet, a district of Rotterdam. Contrary to claims about large, disrupting impacts of urban regeneration, the results show that - even in times of economic crisis - regeneration in Hoogvliet has enabled 'ageing in place'. There appears no relationship between the Hoogvliet policies and changes in income of elderly people and their ability to get by financially. Those who have moved home often report regeneration benefits, mostly related to accessing better quality housing in the same area. Finally, we found no clear evidence of decreased social support or increased loneliness through regenerationinduced disruption of social networks.

JEL Classification: J14, O18, R23

Keywords: $\quad$ ageing in place, urban regeneration, social networks, social support, loneliness, Rotterdam

Corresponding author:

Reinout Kleinhans

Delft University of Technology

Faculty of Architecture and the Built Environment

OTB - Research for the Built Environment

PO Box 5030

Delft, $2600 \mathrm{GA}$

The Netherlands

E-mail: r.j.kleinhans@tudelft.nl 


\section{Introduction}

An important demographic development is the ageing of the population in many countries (WHO, 2007). The growing shares of elderly people raise enormous societal challenges with regard to the size of the work force and the demand for and funding of pensions, health care and other age-related services (for an overview, see Gavrilov \& Heuveline, 2003). An aging population does not only raise financial, macro-economic issues. On the level of cities and neighbourhoods, policymakers increasingly grapple with the question how to accommodate ageing in neighbourhood development and management. For example, many local governments in the Netherlands are now implementing policies that support elderly people to remain and grow old in their current dwellings instead of 'moving' them into old people's homes or nursing homes (Tinker et al., 2013: 18; Dijkhoff, 2014). These policies are not only considered as necessary for decreasing the costs of expensive institutionalized care, but are also regarded positive for the well-being of elderly people (WHO, 2007; Gilroy, 2008; Wiles et al., 2012). They can remain in their own homes and trusted environment as long as their physical and mental health and mobility allows it.

A precondition for the success of such policies is that elderly people feel safe in their homes and that they perceive their neighbourhoods as familiar, safe, clean and a nice place to grow old (Smith, 2009; Davies \& James, 2011; Gardner, 2011; Wiles et al., 2012). Whereas physical measures inside houses to accommodate lower mobility and health problems are relatively straightforward, creating 'age-friendly' neighbourhoods or even cities is much more difficult (Lui et al., 2009; Phillipson, 2011; Buffel et al., 2012). In fact, many less affluent elderly people live in deprived neighbourhoods where low-quality housing, crime, disorder and tensions between ethnic groups, decrease the liveability of the area (Van der Meer et al., 2008; Smith, 2009). Many of these neighbourhoods in Western European countries have been subject to urban regeneration policies. A key element is demolition of cheap social rented housing, new construction of more expensive rental or owner-occupied housing, and renovation of infrastructures and public space. The aim of such policies is often twofold. On the one hand, they aim to improve the liveability and reputation of deprived urban neighbourhoods which are dominated by social housing that were constructed in the 1950s, 1960s and 1970s. On the other hand, these policies aim to improve the lives of residents in those neighbourhoods (Kleinhans, 2004; Davidson et al., 2013; Manley et al., 2013).

An important issue is to what extent recent neighbourhood regeneration policies have resulted in meaningful improvements for elderly people, especially for those who remain living in regeneration areas. Whereas the majority of the literature in this field emphasizes negative regeneration impacts, especially on social networks of the elderly, there is reason to be critical of all-too-easy generalisations about disruptive impacts.

May regeneration evaluations that focus on general populations remaining in target areas (e.g. Mason \& Kearns, 2012; Wilson, 2013) have not specifically targeted elderly people. The same applies to literature reviews of health impacts of housing improvement or wider urban regeneration efforts (for an overview, see Egan et al. 2013). Van der Meer et al. (2008: 62) have called for more research into the impacts of neighbourhood transitions on the well-being of vulnerable older adults. Other research primarily deals with (elderly) people's sense of belonging and place attachment, as well as the 'damage' done by regeneration in this respect (e.g. Phillips et al., 2005; Manzo et al., 2008; Goetz, 2010). On the one hand, elderly people can be adversely affected by rapid changes in the physical fabric and service structure in neighbourhoods and high residential turnover, resulting in disruption of supportive relationships that also prevent loneliness (Scharf \& de De Jong Gierveld, 2008; Sixsmith et al., 2014). On the other hand, urban regeneration may cater for residential environments that facilitate ties between elderly people and supportive network members, and integrate new housing solutions that accommodate (care) needs and thus enable 'ageing in place'. 
Except for qualitative research including multiple contacts with research subjects spanning eight months (Gardner, 2011) or several years (Ziegler, 2012), many studies are cross-sectional and unable to detect patterns over time. However, especially loneliness and (increasing) lack of social support may develop over time in either positive or negative ways. Furthermore, the available research does hardly distinguish between residents who were differently affected by urban regeneration; some stay put in the same dwelling, while others have to move because of demolition or voluntarily move to new dwellings in the same area. This will likely have varying impacts on perceived regeneration benefits or burdens. Finally, little is known about combined impact of regeneration and the economic crisis since 2008. As part of wider government austerity programs, regeneration programs have been slimmed down and the fear is that the crisis may have offset hard-fought program benefits (Kleinhans \& Veldboer, 2012; Curl \& Kearns, 2013).

Considering these caveats, this paper aims to establish medium term impacts of regeneration interventions on housing situation, social support networks and socioeconomic position of elderly people in Hoogvliet, a district at the edge of the city of Rotterdam. This area has been subject to the third largest urban regeneration operation in the Netherlands and is also one of the very few areas in which regeneration impacts have been studied with multiple measurements over time (Veldboer et al., 2007; Kleinhans et al., 2014). Our research question is threefold:

1. How do the socioeconomic and housing characteristics of elderly residents in the regeneration area Hoogvliet change over time?

2. To what extent do differences in housing and neighbourhood benefits occur between long-term stayers and movers to other dwellings in Hoogvliet?

3. To what extent has regeneration affected loneliness and perceived social support in the panel of elderly residents?

We will answer these questions through the analysis of a small but unique panel data set of 160 elderly residents living in Hoogvliet. This enables us to analyse changes on a limited but important range of socioeconomic, housing, neighbourhood and social network indicators. Before we describe the data, methods and results, we first review the academic literature that is relevant for our research questions.

\section{Urban Regeneration and Elderly People}

With urban regeneration policies now being in force for decades, the body of research dealing with various impacts of regeneration and renewal measures is growing steadily, particularly in the United States and the United Kingdom. A particular area of attention are physical and mental health impacts of housing improvement or wider area-based regeneration efforts. This is a field of study in which many systematic reviews are available (Atkinson et al., 2006; Thomson et al., 2006, 2009; Jacobs et al., 2010; Lindberg et al., 2010). While there is some evidence that housing improvement can improve general, mental and respiratory health, Egan and colleagues (2010: e47) have observed that "the evidence base is neither comprehensive nor conclusive, particularly regarding neighborhood-level renewal" and also that "[r]eviews have noted some evidence that such interventions may have unintended consequences" (Thomson et al., 2006). Moreover, the evidence reviews target general populations and not the elderly in particular, which makes it particularly difficult to 'filter out' regeneration outcomes for elderly people. Regardless of positive outcomes, the process of regeneration itself may have adverse impacts. Especially large-scale demolition, vacant dwellings, closing of neighbourhood amenities, the disruption of new construction activities and lack of progress may create frustration, uncertainty and prolonged exposure to deteriorating environmental 
conditions (e.g. Davidson et al., 2013; Kearns \& Mason, 2013), which may in turn negatively affect mental health, especially of elderly people.

Another well-documented strand of research investigates the extent to which urban regeneration affects elderly people's sense of belonging an place attachment (e.g. Ekström, 1994, Phillips et al., 2005; Manzo et al., 2008; Lager et al., 2013). These and other studies have revealed a range of complexities that elderly people have to cope with, and often point at deleterious effects of urban regeneration on elderly people's place attachment. A useful concept has been offered by Rowles and Watkins (2003), who discuss the notion of older adults 'being in place'. This is described as a feeling of being comfortable at home and comfortable with one's environment. The work of Rowles and Watkins (2003) offers a life course approach that is very useful to emphasise the importance of place-making and meaning-making skills developed and accumulated over the life course; these skills help the elderly to cope with environmental change in later life (Ziegler, 2012: 1299). Older adults can become 'out of place' and feel less comfortable with their living environment after changes in their personal situation or during and after radical changes in environment itself. If we translate this to the context of urban regeneration, it is clear that a range of radical changes in terms of housing stock, public space and services, can make people lose their trusted environment (Gilroy, 2008; Van der Meer et al., 2008; Ziegler, 2012; Davidson et al., 2013). According to Jones and Evans (2012), policy rhetoric on the importance of sense of place in regeneration often reveals a sharp contradiction with outputs of the same regeneration schemes that seem to deliberately 'erase' residents' affective connections with place.

On both sides of the Atlantic, a range of studies has focussed on demolition of public or social housing and the related forced relocation of tenants. These studies have paid due attention to experiences of elderly people with the relocation process, explaining social and institutional mechanisms, people's lack of agency, feelings of displacement, disruption of social networks and often eroded well-being (Fried, 1963; Allen, 2000; Ekström, 1994; Greenbaum et al., 2008; Manzo et al., 2008; Van der Zwaard \& De Wilde, 2008; Goetz, 2010; Davidson et al., 2013). This branch of studies seems to dominate the debate on the position of elderly people in urban regeneration, despite evidence of positive outcomes with regard to elderly people's housing situation, especially when they were able to move to new (senior) housing at reduced social rents (e.g. Kleinhans, 2003; Posthumus et al., 2014). Partly for this reason, several authors have criticized the common equation of relocation from restructuring areas with displacement (Kleinhans, 2012; Kearns \& Mason, 2013).

Many of the aforementioned issues, e.g. neighbourhood-induced changes in sense of belonging and disruptions of social networks, can affect loneliness among ageing people. Scharf and De Jong Gierveld (2008: 103-104) identify at least three interrelated processes that fit to the context of urban regeneration. First, older people can be adversely affected by changes in the physical fabric of cities and neighbourhoods. It is obvious that radical changes in the housing stock and forced relocation may disrupt the types of social relationships that may prevent loneliness. Second, older people's social well-being is prone to rapid changes in population composition; these changes result in people losing 'familiar faces' in the neighbourhood, which were important not only in practical terms, but also to their sense of place. Hence, they may feel increasingly like a stranger in their own neighbourhood, as a high residential turnover is a key feature of areas undergoing intensive restructuring. Thirdly, regeneration-related changes in service infrastructure and local shops and the related loss of familiar meeting places may increase reluctance among elderly people to go out on the street to meet friends or acquaintances, thus increasing the risk of loneliness. This links with health and well-being, as "social isolation and loneliness tend to exacerbate personal care needs, whereas socially-included individuals are more likely to participate in the activities that help promote active ageing and reduce care needs” (Tinker et al., 2013: 19). 
According to many, local communities should form a supportive environment for elderly people (Wiles, 2005), but this does not come easily. Comparative research has shown that older people see 'healthy' ageing as an active achievement that must be created through personal effort and supportive ties that enable coping them with the physical and mental challenges associated with old age (Sixsmith et al., 2014). Maintaining social ties, not only with family and friends but also 'meaningful others' within the neighbourhood is crucial to mobilise practical and social support, and preventing loneliness (Gardner, 2011). In fact, much social support is often provided by elderly people themselves. An in-depth study of volunteering in an English deprived community revealed a significant share of older adults among volunteers for organizations providing social welfare services for people (i.e. nonhousehold members) in that community (Hardill \& Baines, 2009). The aforementioned impacts of urban regeneration on social networks and loneliness are also linked with social support. In a longitudinal study of 15 deprived neighbourhoods in Glasgow, Kearns and colleagues (2014) found absence of practical support to be associated with frequent loneliness.

Recently, the continuing economic crises in many European countries has fuelled concerns about the income position of elderly people, at least in the Netherlands. Many people feel that not only the young and working people are affected by the crisis, but also the elderly. However, a national study of various age groups in society has revealed that those aged years and older have experienced stronger income increases than younger people. The share of people aged 65+ who reports that they can (very) easily get by on their disposable household income has increased from 40\% in 1991 to 63\% in 2011 (Soede, 2012). A large part of Dutch society holds a persistent stereotype that many elderly people are poor, despite the availability of objective data showing a completely different picture (Van Dalen \& Henkens, 2013). Although the expected (causal) relations between income changes of elderly people and regeneration interventions are unclear in the (policy) literature, there are reasons to explore the link in this paper. As regeneration policy targets deprived areas with concentrations of low-income households, it is unsure whether the national figure on $63 \%$ getting by, also applies to residents in deprived areas. Urban regeneration may directly lower their disposable income by relocating them to more expensive (social) housing, or indirectly by neighbourhood resource displacement, i.e. disappearance or upgrading of local shops, services and meeting places so that incumbent residents cannot use them anymore and turn to more expensive alternatives (Davidson, 2008: 2392).

Another important factor to consider is that the crisis has delayed, slimmed down or cut regeneration policies as part of government austerity programs, also in the Netherlands. The crisis may have offset hard-fought program benefits (Curl \& Kearns, 2013; Wilson, 2013: 191) for example by laying off people who were helped into paid employment, or local support programs for older residents. Macro-economic implications of the economic crisis include increasing the cost of living for elderly people by lowering housing and health care allowances and not indexing their pensions. Subsequently, elderly people may have fewer opportunities to visit family or friends and to participate in leisure activities or voluntary associations, thus further increasing (the risk of) social isolation. The combination of macroeconomic developments and cut programs emphasizes the need to look at how regeneration benefits have developed from the situation before the crisis to its recent culmination.

Based on this literature review, we seek to analyse the following matters: 1) changes in the housing situation and socioeconomic characteristics of elderly residents in Hoogvliet over time; 2) differences in housing and neighbourhood benefits between long-term stayers and movers to other dwellings in Hoogvliet, and 3) changes in loneliness and perceived social support in a panel of elderly residents. 


\section{Context, data and methods}

\subsection{Research Area}

The Dutch city of Rotterdam expanded rapidly following the Second World War, largely due to housing shortages caused by war damage. Hoogvliet, a district in the south-western part of the city, was built mainly during the 1960s and was created to house employees in the nearby petrochemical industry. In the following decades, however, economic recessions and restructuring adversely affected the industry and unemployment rose rapidly. Early in the 1990s, the district authorities launched a social regeneration policy to reverse the decline of Hoogvliet. This social approach paved the way for a large-scale urban restructuring project that started in 1999 and is now nearing completion (Veldboer et al., 2007). The project will transform the housing stock by demolishing 5,000 social rented dwellings and replacing them with more expensive rental and owner-occupied properties, and selling off 1,500 social rented dwellings (ODPM, 2006). The key principles of the renewal were framed in terms of improving collective (local economy in the district, social cohesion, housing stock, public space, civic involvement and reputation) and individual goals such as improvement of the residents’ social economic position (Deelgemeente Hoogvliet, 1999; ODPM, 2006).

\section{Figure 1 The Sarahburcht ${ }^{1}$}

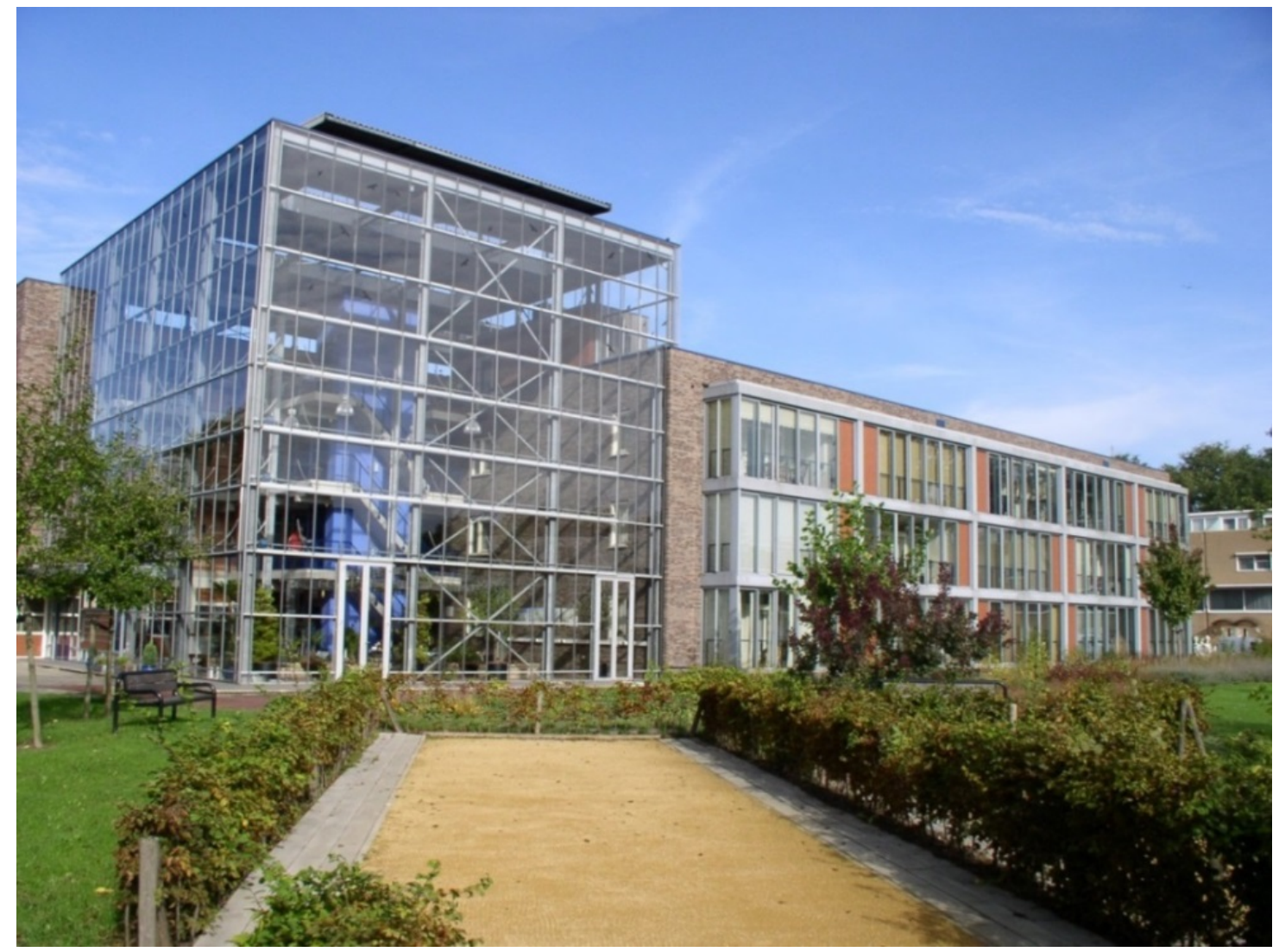

Photo: First author.

As part of the aim to improve social cohesion, particular attention was devoted to elderly people who were facing consequences of the regeneration process, especially in cases of relocation due to demolition of social rented dwellings. A so-called 'senior citizens brigade' (seniorenbrigade) was established in which senior citizens are helping each other out with

\footnotetext{
${ }^{1}$ The name 'Sarah' refers to a Dutch tradition in which a woman who reaches the age of 50 is called Sarah. For men, the name connected to 50 is Abraham.
} 
various problems (ODPM, 2006: 100). Another instrument are 'neighbourhood houses' (praathuizen). These are vacant social rented dwellings accommodated by the housing association to serve as meeting spots for elderly people. These meeting places were also used by housing association or local authority councillors to exchange information and provide support in various stages of the regeneration (Deelgemeente Hoogvliet, 1999, ODPM, 2006: 100). Elderly residents who were relocated to new social rented dwellings not only received the formal compensation for moving costs, but also received discounts on standard rents that would be charged to for example new residents from outside Hoogvliet. This strategy aimed to increase the affordability of new dwellings and to minimize financial stress for older movers. Finally, some self-organised groups of elderly residents were active agents within the process. They wanted to stay together after demolition of their dwellings, joined forces and negotiated an active role in the design of replacement housing, targeting their housing preferences and future social care needs. This resulted in the development of housing communes (such as the 'Sarahburcht' (see Figure 1) and the 'Noorderbaken' where groups of people aged 50 years and older will be living in houses partly designed by themselves and developed by the housing associations (ODPM, 2006: 103).

\subsection{Data and analysis}

Our primary interest lies with residents who were about to reach the formal Dutch pension age in 2012. The reason is that socioeconomic mobility is usually (almost) non-existent among people who have retired and left paid employment by this age. We are particularly focusing on residents who were approximately 50 years or older when the regeneration started in 1999, and who now have reached the age of 63 and older. While the formal Dutch pension age was 65 years (in 2012), Dutch population statistics show that by the age of 63, only a small fraction is still active in paid employment, while the majority has retired. Hence, we will use this cut-off for our analysis.

Figure 2 The timeline

\begin{tabular}{|c|c|c|c|c|c|}
\hline \multirow[b]{2}{*}{$t_{1}$} & \multicolumn{3}{|c|}{ Start of the renewal } & Baseline $t_{0}$ & \multirow[t]{2}{*}{ Follow up } \\
\hline & 1999 & $<-$ retrosnective & $<-$ & 2007 & \\
\hline Age: & $50+$ & & & $58+$ & $63+$ \\
\hline
\end{tabular}

We use a panel dataset based on large surveys conducted in 2007 and 2012, as part of a longitudinal research project on the outcomes of urban regeneration in Hoogvliet. This approach is partly in response to observations from a systematic evidence review that panel surveys to assess impacts on the original residents in the context or area-based initiatives are rare (Thomson et al., 2006: 113; Wilson, 2013: 178). In 2007, we completed a mixedmethods study of experiences and perceptions of long-term stayers and movers within Hoogvliet, i.e. all residents who remained in the Hoogvliet district during the period 19992007 (Veldboer et al., 2007). Lacking a proper baseline measurement in 1999, this particular study used a retrospective survey to reveal perceived changes in a set of neighbourhood and individual indicators that may have been affected by various regeneration measures, such as housing and neighbourhood satisfaction, levels of social and physical disorder, and social cohesion and collective efficacy. From a population of approximately 6,000 households, the survey yielded a response of $1,684(25 \%)$ usable questionnaires, of which half $(n=841)$ was returned by respondents who were 63 or older. Non-response analysis (not shown here) has revealed that ethnic minorities were slightly underrepresented, but elderly people were strongly overrepresented (Veldboer et al., 2007). For the purposes of our paper, the latter 
outcome was useful for increasing the potential size of a panel of elderly residents. In the 2007 survey, we asked respondents' consent for contacting them for subsequent research.

In 2012, we set out a much larger survey for a follow-up study with a wider scope, i.e. also including residents who had moved into the district from other parts of Rotterdam or be beyond (Kleinhans et al., 2014). This survey was predominantly based upon a random sample of adult residents in Hoogvliet, but also on a population administration data check of respondents of the 2007 survey, in order to approach them again for the follow-up survey. As a result of missing address data, residential mobility, deaths and other life cycle events, only a quarter of the respondents from 2007 could be retraced in 2012. In the end, this yielded a panel of 160 respondents aged 63 years or older who were interviewed in both years. Their common characteristic is that they have lived in Hoogvliet since the start of the regeneration project in 1999 (see Figure 2) and have either lived in the same dwelling since then (stayers) or have moved to another dwelling within the district Hoogvliet (movers). In other words, this panel of residents has been fully exposed to the regeneration from the very beginning to date. Appendix A lists the demographic characteristics of the respondents. Two-thirds are men, one third are women. Almost half of the respondents are aged 63-74 years and 44 per cent are aged 75-84 years. In terms of household composition, 36 per cent are single and 56 are couples without children living at home. And 90 per cent are native Dutchmen; the remainder have a background mostly in Surinam or Indonesia.

We focus our analysis on changes in socioeconomic position, housing situation, and indicators of social support and loneliness. Interestingly, timing of the measurements allows an indication of the extent to which the economic crises has affected this groups. The first measurement (2007) was conducted before the start of the economic crisis (early 2009), while the second measurement coincides with its peak (2012), at least in public perception.

Because assessment is based on change for individuals, analyses will automatically control for fixed person specific latent characteristics, such as a respondents gender or a trait of extraversion, which may influence the propensity to record a given outcome (see Wilson, 2013: 178). Unfortunately, we have no control group for this panel, so we cannot establish with full certainty whether the reported changes are the result of regeneration measures or other factors in time. This problem is partly overcome by using survey questions include an explicit link between regeneration and certain outcomes.

Depending on the nature of the relationships tested and the measurement level of the variables, we have applied a number of statistical techniques ${ }^{2}$, such as Fischer's Exact test, McNemar change test, Chi-square test, Mann-Whitney test, Wilcoxon Sign Rank test, and Marginal Homogeneity test. Below, the main results will be described.

\section{Results}

\subsection{Changes in perceived income and housing situation}

With a few exceptions, all panel respondents are social renters. In Table 1, a limited number of moves between 2007 and 2012 can be observed when looking at housing type. A small number has moved from single-family dwellings to independent apartments, special elderly housing or an apartment in a commune for elderly people; the Saraburcht and Noorderbaken (Figure 1) are examples of this new type of housing in Hoogvliet.

\footnotetext{
${ }^{2}$ Fischer's Exact test: two independent samples, categorical measurement level. McNemar change test: two dependent samples, categorical measurement level. Chi-square $(x 2)$ test: two or more independent samples, categorical measurement level. Mann-Whitney U-test: two independent samples, ordinal measurement level. Wilcoxon Sign Rank test: two dependent samples, ordinal measurement level. Marginal Homogeneity test: more than two dependent samples, categorical measurement level.
} 
Table 1

Changes in housing and socioeconomic situation

Indicato $t_{0}(2007) \quad t_{1}$ (2012)

Test type

Statistic

p

n

Housing Tenure

- Social rent

- Owner occupation

$149 \quad 93.1$

n \%

- Unknown

$\begin{array}{rrrr}7 & 93.1 & 143 & 89.4 \\ 7 & 4.4 & 7 & 4.4 \\ 4 & 2.5 & 10 & 6.3\end{array}$

McNemar

N.A.***

1.000

Housing Type:

- Single-family dwelling

- Apartment (independent)

- Special elderly housing

- Apartment in commune

- Other

Income source:

- Salary (employment)

- Retirement

- Social benefits

Use of allowances:

- Housing allowance

- Care allowance

- No allowance at all

Disposable income:

$\begin{array}{rrrr}71 & 44.4 & 62 & 38.8 \\ 64 & 40.0 & 67 & 41.9 \\ 15 & 9.4 & 19 & 11.9 \\ 7 & 4.4 & 10 & 6.3 \\ 3 & 1.9 & 2 & 1.2\end{array}$

Std. $\mathrm{MH}$

0.846

$\begin{array}{llll}18 & 11.3 & 7 & 4.4\end{array}$

$\begin{array}{llll}129 & 80.6 & 148 & 92.5\end{array}$

McNemar

N.A.***

0.003

$\chi^{2}=12$

0.001

$\begin{array}{lllll}9 & 5.7 & 4 & 2.5 & \text { McNemar }\end{array}$

N.A.***

0.508

$\begin{array}{llll}51 & 31.9 & 58 & 36.3\end{array}$

McNemar

N.A.***

0.210

$\begin{array}{llll}86 & 53.8 & 109 & 68.1\end{array}$

McNemar

$\begin{array}{llll}50 & 31.3 & 40 & 25.0\end{array}$

McNemar

$\chi^{2}=9.787$

0.002

$\chi^{2}=1.929$

0.165

- Increased

$\begin{array}{rrrrr}24 & 15.0 & 20 & 12.5 & \text { Marginal } \\ 79 & 49.4 & 95 & 59.4 & \text { Homogeneity } \\ 51 & 31.9 & 42 & 26.3 & \\ 6 & 3.8 & 3 & 1.9 & \end{array}$

Std. $\mathrm{MH}$

0.536

- Remained stable

- Decreased

- Unknown

$\begin{array}{llll}6 & 3.8 & 3 & 1.9\end{array}$

Coping financially:

- Easier than before

- No difference

- More difficult than before

$\begin{array}{llll}10 & 6.3 & 15 & 9.4\end{array}$

Marginal

Std. $\mathrm{MH}$

0.619

69

43.1

$91 \quad 56.9$

Homogeneity

0.002

$\begin{array}{llll}66 & 41.3 & 50 & 31.3\end{array}$

3.101

- Unknown

$\begin{array}{llll}15 & 9.4 & 4 & 2.5\end{array}$

Changes in savings

- More savings

$\begin{array}{rrrrr}14 & 8.8 & 17 & 10.6 & \text { Marginal } \\ 33 & 20.6 & 48 & 30.0 & \text { Homogeneity } \\ 67 & 41.9 & 61 & 38.1 & \\ 31 & 19.4 & 28 & 17.5 & \\ 15 & 9.4 & 6 & 3.8 & \end{array}$

Std. $\mathrm{MH}$

0.100

- Roughly the same

- Less savings

- Unknown

$24 \quad 15$

$$
9 \quad 5.6
$$

McNemar

N.A.***

0.004

Respondent has debts
Changes in loans/debts:

- Debts have decreased

$$
13
$$

$8.1 \quad 8 \quad 5.0$

Marginal

Std. $\mathrm{MH}$

0.083

- Debts remained stable

- Debts have increased

$\begin{array}{llll}10 & 6.3 & 3 & 1.9\end{array}$

- Not applicable $\begin{array}{llll}124 & 77.5 & 137 & 85.6\end{array}$

Source: panel data extracted from surveys 2007 and 2012. Significant $\mathrm{p}$-values $(\mathrm{p} \leq 0.05)$ are printed in bold.

*** In some cases, SPSS does not provide a $\chi^{2}$ test statistic for the McNemar test, but only a p-value. This is because SPSS calculates the p-value differently depending on the number of discordant pairs in the cross table 
that compares the measurements (LaerdStatistics, 2014). If the number of discordant pairs is small, the McNemar test $\chi^{2}$ is not well approximated by the $\chi$-squared distribution. In such cases (a rule of the thumb is N_D $<25$ ) a two-tailed exact test based on a binomial distribution is used by SPSS and no separate test statistic is reported.

Now we turn to the most important sources of income, including official allowances. In Table 1 , note that we have reported these as dichotomous variables, as residents could more than one income source in the survey. This is also why we used the McNemar test. While we cannot exclude a crisis effect (redundancies), ageing has further decreased the already limited share of respondents with paid employment on $t_{0}$ to $t_{1}$. The share of retired people peaks at 93 per cent. The increasing age also affects the use of allowances. ${ }^{3}$ Housing allowances has grown from 32 to 36 per cent. More strikingly, the share of health care allowances has increased from 54 to 68 per cent, i.e. two-thirds of the panel.

Subsequently we analyse the perceived income situation of the panel. Lacking proper objective income data, we compare perceived disposable income change, the ability to get by financially, and changes in savings and debts/loans over the years. First, we find a quite stable pattern in the perceived income changes over the preceding years, both for $t_{0}$ and $t_{1}$. Approximately 14 percent has reported an increase, while roughly 30 per cent perceives a decrease. The differences between 2007 and 2012 are not statistically significant. Secondly, the share of respondents claiming to get by more easily has increased slightly (from 6 to 9 per cent). Simultaneously, the share of people experiencing more difficulties to get by, has decreased (from 41 to 31 on $t_{0}$ and $t_{1}$ respectively). So whereas the perceived disposable income has not changed significantly, respondents perceive to be slightly but significantly more able to get by financially. However, getting by more easily does not mean that people increase their savings. There is no significant change in the reported (in)ability to save money. Finally, the share of respondents reporting consumer loans (debts) ${ }^{4}$ has decreased from 15 to 6 per cent. All in all, the data do not reveal substantial volatility in the reported income data. If anything, the socioeconomic position of the panel seems to have improved slightly since 2007. While we cannot establish the extent to which retirement was a result of redundancies, the share of retired people has significantly decreased the share of people that may lose their job due to the economic crisis.

\subsection{Attribution of individual and neighbourhood benefits to regeneration}

In section 3.2, we explained that the $2007\left(\mathrm{t}_{0}\right)$ and $2012\left(\mathrm{t}_{1}\right)$ questionnaires were only partly identical. This is the result of the differences in focus between the two studies that are at the basis of our panel. In the 2012 survey, we have asked respondents to reflect upon the extent to which they feel that changes in their own personal situation and development of their neighbourhood can be attributed to regeneration interventions (especially demolition of unattractive social housing, new construction of higher-quality social or owner-occupied housing, improvement of public space, and so on - see section 3.1 and Kleinhans et al., 2014). These data are not available for 2007.

\footnotetext{
${ }^{3}$ In the Netherlands, two types of allowances are relevant with regard to the disposable income of elderly people: health care and housing allowances. Health care allowances have been introduced as part of a reform in private health insurance in 2006. Through the Healthcare Allowance Act (Wet op de Zorgtoeslag), households with lower incomes are financially compensated for paying the obligatory fees to private insurance on a monthly basis (Van Ginneken et al. 2008). Housing allowances are a means to making rental housing of a certain quality available to low-income tenants. Established in the Housing Allowance Act (Huursubsidiewet) of 1997, the subsidy varies with the rent level, household income and household size (see Priemus et al., 2005 for a detailed explanation).

${ }^{4}$ With loans, we exclude mortgages connected to owner-occupied housing.
} 


\begin{tabular}{|c|c|c|c|c|c|c|c|}
\hline \multirow[t]{2}{*}{ Indicator } & \multicolumn{2}{|c|}{$\begin{array}{l}\text { Movers } \\
(n=39)\end{array}$} & \multicolumn{2}{|c|}{$\begin{array}{l}\text { Stayers } \\
(n=119)\end{array}$} & \multirow[t]{2}{*}{ Test type } & \multirow[t]{2}{*}{$\begin{array}{r}\text { Test } \\
\text { statistic }\end{array}$} & \multirow[t]{2}{*}{$\begin{array}{r}p- \\
\text { value }\end{array}$} \\
\hline & $n$ & $\%$ & $n$ & $\%$ & & & \\
\hline \multicolumn{8}{|l|}{ Housing Type: } \\
\hline - Single-family dwelling & 2 & 5.1 & 59 & 50.0 & Fisher’s & 38.541 & 0.000 \\
\hline - Apartment (independent) & 20 & 51.3 & 47 & 39.8 & Exact Test & & \\
\hline - Special elderly housing & 10 & 25.6 & 8 & 6.8 & & & \\
\hline - Apartment in commune & 7 & 17.9 & 3 & 2.5 & & & \\
\hline \multicolumn{8}{|l|}{$\begin{array}{l}\text { Changes in housing } \\
\text { situation: }\end{array}$} \\
\hline - No change & 10 & 30.3 & 96 & 93.2 & Fisher’s & 57.990 & 0.000 \\
\hline - Bought rental dwelling & 0 & 0 & 2 & 1.9 & Exact Test & & \\
\hline - Moved to new construction & 12 & 36.4 & $* * * 1$ & 1.0 & & & \\
\hline - Moved to existing dwelling & 8 & 24.2 & $* * * 3$ & 2.9 & & & \\
\hline - Other & 3 & 9.1 & 1 & 1.0 & & & \\
\hline \multicolumn{8}{|l|}{$\begin{array}{l}\text { Experienced personal benefit } \\
\text { due to regeneration? }\end{array}$} \\
\hline - Yes & 21 & 61.8 & 27 & 23.5 & $\begin{array}{l}\text { Chi- } \\
\text { Square }\end{array}$ & $\chi^{2}=17.72$ & 0.000 \\
\hline - No & 12 & 35.3 & 78 & 67.8 & & & \\
\hline - Don’t know & 1 & 2.9 & 10 & 8.7 & & & \\
\hline \multicolumn{8}{|l|}{$\begin{array}{l}\text { Neighbourhood change in } \\
\text { the past few years: }\end{array}$} \\
\hline - Improved & 16 & 43.2 & 25 & 21.7 & $\begin{array}{l}\text { Chi- } \\
\text { Square }\end{array}$ & $\chi^{2}=11.10$ & 0.004 \\
\hline - Remained stable & 19 & 51.4 & 58 & 50.4 & & & \\
\hline - Declined & 2 & 5.4 & 32 & 27.8 & & & \\
\hline \multicolumn{8}{|l|}{$\begin{array}{l}\text { Is neighbourhood change an } \\
\text { effect of regeneration (RG)? }\end{array}$} \\
\hline - Completely thanks to the RG & 6 & 18.8 & 12 & 10.9 & Mann- & 1387.5 & 0.05 \\
\hline - Partly thanks to the RG & 13 & 40.6 & 35 & 31.8 & $\begin{array}{r}\text { Whitney } \\
\text { U }\end{array}$ & & \\
\hline - Hardly thanks to the RG & 6 & 18.8 & 21 & 19.1 & & & \\
\hline - Not at all related with RG & 7 & 21.9 & 42 & 38.2 & & & \\
\hline
\end{tabular}

Source: panel data extracted from surveys 2007 and 2012. Significant $\mathrm{p}$-values $(\mathrm{p} \leq 0.05)$ are printed in bold.

***These are respondents who have ignored the routing in the original questionnaire; they have not moved in the years 2007-2012, but before this period; they nevertheless filled out the question about housing changes in this period of time.

In order to link panel member perceptions of regeneration benefits to the actual regeneration interventions, we distinguish between panel members who moved due to the regeneration (movers) and those who remained in the same dwelling between t 0 and $\mathrm{t} 1$ (stayers). In other words, the first group was directly affected through a move within the regeneration area, regardless of whether this move was voluntary or involuntary. Thus, any between-group differences in perceived regeneration benefits are likely to be connected with changes (or a lack thereof) in the housing situation.

Table 2 shows that stayers more often live in a single-family dwelling, while movers significantly more often reside in a (new) independent apartment, special elderly housing or an apartment in a commune, such as the Sarahburcht or the Noorderbaken (see Fig. 1 \& 2). Not surprisingly, almost all stayers reported no changes in the housing situation. This applies to almost one third of the movers. More than $60 \%$ of the movers reports a personal benefit 
from regeneration, compared to only a quarter among the stayers. Other 2012 survey data (not reported here) show that these personal benefit are mostly connected to changes in the housing situation, such as higher overall dwelling quality, insulation, better kitchen and bathrooms, and more space.

Movers are much more positive than stayers about the changes in their current neighbourhood. Whereas 43 per cent of the movers feel that their neighbourhood has improved, the share of stayers reporting this outcome is about half this share (22 per cent). This difference can be primarily explained by moving to new construction, to other ('better') neighbourhoods within Hoogvliet, or a combination of these two factors. And whereas 28 per cent of the stayers reports 'decline', only five per cent movers has the same feeling. Finally, movers significantly more often attribute neighbourhood changes to regeneration than stayers. Further analyses (not shown here) indicate that there are no stayers who attribute perceived neighbourhood decline to regeneration efforts.

\subsection{Changes in social support and loneliness}

As described in section 2, large-scale demolition and relocation may have disrupted socially supportive ties of elderly people, for whom a (strong) social network is crucial to mobilising practical and social support, and preventing social isolation and loneliness (Gardner, 2011). While preventing social isolation has not been a key aim in the regeneration of Hoogvliet, this issue received much attention during the process, not only with regard to elderly people who had to cope with forced relocation, but also with elderly people who remain living in the same dwelling. Various instruments such as the aforementioned 'senior citizens brigade' (see section 3.1) were deployed to tackle social exclusion and to prevent unintentional harm as a result of relocation out of the trusted and familiar environment.

In order to measure support and loneliness, the 2007 and 2012 surveys included three 5-point Likert scale items (strongly disagree ... strongly agree). As there are only three items, exploratory or confirmatory factor analysis is not an option. Moreover, Cronbach's $\alpha$ of the combined items is below the usual 0.7 cut-off, so the items cannot be combined into one index measure. Thus, we analyse each item separately (see Table 3). The items are:

1. In case of emergency, I can always call on someone close by for help

2. I have to solve many problems myself as I get support from very few people

3. I often feel lonely.

For item 1 (emergency support) we found no significant difference between $t_{0}$ and $t_{1}$. So there appears no change in the perceived (level of) emergency support of panel members. For item 2 (lack of social support), we find that similar shares of respondents agree with the proposition on $t_{0}$ and $t_{1}$. However, the share of respondents who strongly disagree with the proposition has significantly decreased over time, i.e. from 13 per cent in 2007 to 3 per cent 2012. Since the share of people disagreeing has decreased, it appears that the perceived level of social support has slightly decreased over time, with the difference between 2007 en 2012 being significant. A similar pattern applies to item 3 (loneliness), with a decrease of 14 per cent strongly disagreeing with the statement. Thus, the level of loneliness seems to have slightly increased between 2007 and 2012.

While the differences for both items are statistically significant, there is no evidence for a straightforward deterioration in the levels of social support and loneliness. Such a trend should have been reflected in higher shares of panel members who (strongly) agree with both negative statements. Considering this and the fact that the observed changes between $t_{0}$ and $t_{1}$ are connected to low numbers of respondents, we see no reason to apply multivariate modelling to the indicators of loneliness and social support. Further bivariate analysis (not shown here) reveals that the aforementioned changes only apply to stayers in the same dwelling. Among movers, the differences between $t_{0}$ and $t_{1}$ are not statistically significant. 
Hence, respondents who were directly affected by urban regeneration (through a move) have not reported changes in their perceived levels of support and loneliness. In contrast, in the literature, this category is often supposed to be most negatively affected.

Table 3 Changes in social support and loneliness $2007-2012(\mathrm{n}=160)$

\begin{tabular}{|c|c|c|c|c|c|c|c|}
\hline \multirow[t]{2}{*}{ Indicator } & \multicolumn{2}{|c|}{$t_{0}(2007)$} & \multicolumn{2}{|c|}{$t_{1}(2012)$} & \multirow[t]{2}{*}{ Test type } & \multirow[t]{2}{*}{ Statistic } & \multirow[t]{2}{*}{$p$} \\
\hline & $n$ & $\%$ & $n$ & $\%$ & & & \\
\hline \multicolumn{8}{|l|}{ Emergency support } \\
\hline - Strongly agree & 52 & 35.4 & 39 & 25.5 & $\begin{array}{r}\text { Wilcoxon } \\
\text { Sign }\end{array}$ & $\begin{array}{c}Z=- \\
0.984\end{array}$ & 0.325 \\
\hline - Agree & 62 & 42.2 & 76 & 49.7 & Ranks Test & & \\
\hline - Neither agree nor disagree & 21 & 14.3 & 29 & 19.0 & & & \\
\hline - Disagree & 5 & 3.4 & 6 & 3.9 & & & \\
\hline - Strongly disagree & 7 & 4.8 & 3 & 2.0 & & & \\
\hline \multicolumn{8}{|l|}{ Lack of social support } \\
\hline - Strongly agree & 13 & 9.2 & 16 & 10.8 & $\begin{array}{r}\text { Wilcoxon } \\
\text { Sign }\end{array}$ & $\begin{array}{l}Z=- \\
2.711\end{array}$ & 0.007 \\
\hline - Agree & 22 & 15.5 & 24 & 16.2 & Ranks Test & & \\
\hline - Neither agree nor disagree & 54 & 38.0 & 68 & 45.9 & & & \\
\hline - Disagree & 34 & 23.9 & 35 & 23.6 & & & \\
\hline - Strongly disagree & 19 & 13.4 & 5 & 3.4 & & & \\
\hline \multicolumn{8}{|l|}{ Feel often lonely } \\
\hline - Strongly agree & 4 & 3.0 & 6 & 4.0 & $\begin{array}{r}\text { Wilcoxon } \\
\text { Sign }\end{array}$ & $\begin{array}{l}Z=- \\
2.768\end{array}$ & 0.006 \\
\hline - Agree & 12 & 8.9 & 12 & 8.0 & Ranks Test & & \\
\hline - Neither agree nor disagree & 13 & 9.6 & 31 & 20.7 & & & \\
\hline - Disagree & 56 & 41.5 & 67 & 44.7 & & & \\
\hline - Strongly disagree & 50 & 37.0 & 34 & 22.7 & & & \\
\hline
\end{tabular}

\section{Discussion}

With rapidly ageing populations in many European cities, there is a strong need for knowledge about 'ageing in place', also in neighbourhoods that have been subject to urban regeneration. The extensive literature on regeneration impacts reveals various outcomes for the general population, but limited knowledge on the changing position of elderly people during the regeneration operation. The available knowledge tends to emphasize negative accounts, which has resulted in too-easy claims about disruptive impacts on elderly people. For this reason, we have analysed a small but unique panel data set of 160 elderly residents who have lived through intensive urban regeneration in Hoogvliet, a district of Rotterdam. We have analysed their housing situation (distinguishing between stayers and movers), social support networks and socioeconomic position, as these factors strongly assist their ability to live independently and to 'age in place' (Sixsmith et al., 2014).

There is an increasing popular belief that elderly people have suffered in economic terms due to the crisis and austerity programs in many European countries, including the Netherlands (Van Dalen \& Henkens, 2013). Others fear that the crisis may have offset regeneration program benefits, also for elderly people (Kleinhans \& Veldboer, 2012; Curl \& Kearns, 2013). Analysing panel data from before and during the crisis, such fears should materialize in various socioeconomic status indicators. However, we found a relatively stable pattern in self-reported data on disposable household income and older people's ability to get by financially. If anything, the socioeconomic position of the panel has even slightly 
improved since 2007, discarding an independent negative effect of the crisis. It is very likely that a combination of factors has buffered negative influences, through lower tax rates after retirement, increased use of health care allowances and a restrained rent development that was common in the Dutch social rented sector during the years until 2012. Lacking actual rent price data, we cannot establish to what extent rent discounts (see section 3.1) have contributed to the overall picture, but we may assume that these discounts have helped in bridging any financial gaps between old and new dwellings for relocatees. Finally, it should be noted that part of the popular beliefs about the negative impacts of austerity programs may probably only materialize from 2015 onwards, when cuts in care budgets for elderly people and largescale decentralisation of care come into effect (Tinker et al., 2013; Dijkhoff, 2014). In sum, our findings contradict the pessimist scenario that portrays elderly people as victims from a double-edged sword of urban regeneration and the economic crisis.

We analysed to what extent differences in housing and perceived neighbourhood benefits appeared between long-term stayers and movers to other dwellings in regeneration areas. We found that almost two-thirds of the movers reports a personal benefit from the regeneration, compared to only a quarter among the stayers. These benefits are mostly related to movers' ability to access newly constructed housing within the regeneration area, but also to other, related housing (pull) factors. Likewise, movers are much more positive about (their own) neighbourhood change and significantly more often attribute these changes to the regeneration efforts. The latter finding is likely a selection effect. Prospective movers had various options, i.e. moving out of Hoogvliet or moving to another dwelling in the regeneration area. The second option would appeal only to those movers who were already positive about the development of the area and/or particular neighbourhoods within Hoogvliet, or to those who had other pressing reasons to stay in Hoogvliet, such as the presence of important social ties and attachment to the area. Accessing new dwellings in physically improving neighbourhoods would logically result into more positive views of neighbourhood change (e.g. Posthumus et al., 2014).

Regardless of benefits, literature has shown that elderly people can suffer in various ways from prolonged exposure to intensive urban regeneration approaches. The potential harm includes stress that is connected to forced moves, either temporary or permanent due to demolition or intensive upgrading (Allen, 2000; Ekström, 1994; Kleinhans, 2003), losing one's sense of home and belonging in the neighbourhood (e.g. Lager et al. 2013; Manzo et al., 2008) or stress due to radical physical and population changes in one's immediate living environment (Rowles \& Watkins, 2003; Van der Meer et al., 2008). Using social support and loneliness indicators, we found that the perception of these indicators has slightly changed over time. This change is visible in a decrease of the number of respondents disagreeing with the associated negatively stated questionnaire items. Further analysis has revealed that these changes only appear among stayers and not among movers within Hoogvliet. While these findings suggest decreased social support and increased loneliness, this interpretation is rather short-sighted. In case of a direct negative impact of urban regeneration, we should have seen substantially higher shares of respondents (strongly) agreeing with both survey items on social support and loneliness, but that is not the case. The finding that the small but significant changes only occur among stayers seems counter-intuitive, as negative effects of urban regeneration are often associated with forced moves (e.g. Fried, 1963; Ekström, 1994; Kleinhans, 2003; Greenbaum et al., 2008; Goetz, 2010). In the case of stayers, changes in population and regeneration-induced changes in their daily living environment may have contributed to increasing loneliness and the feeling of decreasing social support, as they stay put in the same dwelling (e.g. Gilroy, 2008; Ziegler, 2012). The fact that we did not find any changes in perceived support and loneliness among movers may be explained in various ways. First, the move was at a short distance, leaving intact crucial supportive ties. Second, several movers voluntarily relocated into elderly housing or apartments in communes such as the 
Saraburcht and the Noorderbaken (see Fig. 1 \& 2). These communes are the result of close ties between people that wanted to stick together and materialised this desire by venturing into design collectives with the housing association in order to build this type of community housing (see also Veldboer, 2010: 141). We therefore conclude that there is no evidence for a straightforward deterioration in the levels of social support and loneliness due to the regeneration. The small changes in these items are much more likely the result of 'natural losses' in people's networks due to their ageing.

There are some limitations to this study. Obviously, the sample size and the specific characteristics of this case study limit the generalizability of findings. The relatively low response are common among field studies in Dutch regeneration research, but this probably results in selection bias (see also Egan et al., 2014: e51). The loss of respondents between 2007 and 2012 is somewhat larger that could be expected from illness, disability and deaths so we assume that the loss of respondents between to measurements is partly selective. However, it is unlikely that this selection has resulted in overly positive results. In our larger study (Kleinhans et al. 2014) we found that many elderly respondents seized the opportunity offered by the survey to complain about a wide range of issues, both related and unrelated to local regeneration. Finally, the original research underlying this panel analysis aimed at establishing the effects of a number of (primarily physical) regeneration interventions, but not particular social measures such as the 'senior citizens brigade', counselling procedures and meeting points (see section 3.1). While these measures may have alleviated negative regeneration impacts, our data do not allow for proper evaluation of their implications.

Despite these limitations, our findings provide reason to be very critical towards straightforward claims about the disrupting impact of urban regeneration. The majority of research supporting such claims is conducted in the context of American public housing renewal, which is much 'harsher' in many respects than the Dutch approach in general and the approach in Hoogvliet in particular (see also ODPM, 2006). Further research is required to explore the generalizability of our findings and to take into account the role of rapidly changing policy contexts, such as the decentralisation of homecare for the elderly (see Dijkhoff, 2014) and the rise of small bottom-up practices of urban regeneration that replace former top-down approaches. Regardless of policies, 'ageing in place' will remain important in the sense that elderly people want to live comfortably in their homes and in familiar, safe, and clean neighbourhoods (Davies \& James, 2011; Gardner, 2011; Wiles et al., 2012). Hence, the search for attractive 'geographies of ageing' continues.

\section{Acknowledgements}

The research leading to these results has received funding from Platform 31 in The Hague, as part of the program "Knowledge for Strong Cities" (Grant no. KKS2-2012-02), and also from Platform Corpovenista in Rotterdam, the housing associations Vestia and Woonbron, and the local authorities of Hoogvliet.

\section{References}

Allen, T., 2000. Housing Renewal—Doesn’t it Make You Sick? Housing Studies, 15 (3), 443461.

Atkinson, R., Thomson, H., Kearns, A., \& Petticrew, M.. 2006. Giving urban policy its' medical': assessing the place of health in area-based regeneration. Policy \& Politics, 34 (1), 5-26.

Buffel, T., Phillipson, C., \& Scharf, T., 2012. Ageing in urban environments: Developing 'age-friendly' cities. Critical Social Policy, 32 (4), 597-617.

Curl, A., \& Kearns, A., 2013. Financial stress and mental wellbeing in an age of austerity: evidence from the GoWell surveys 2006-2011. Gowell, Glasgow. 
Dalen, H., \& Henkens, K., 2013. Hardnekkige beelden over armoede onder ouderen. Demos: bulletin over bevolking en samenleving, 29.

Davidson, M., 2008. Spoiled mixture: where does state-led 'positive' gentrification end? Urban Studies, 45 (12), 2385-2405.

Davidson, G., McGuinness, D., Greenhalgh, P., Braidford, P., \& Robinson, F., 2013. 'It'll get worse before it gets better': Local experiences of living in a regeneration area. Journal of Urban Regeneration and Renewal, 7 (1), 55-66.

Davies, A., \& James, A., 2011. Geographies of ageing: Social processes and the spatial unevenness of population ageing. London, Ashgate Publishing, Ltd.

Deelgemeente Hoogvliet, 1999. Hoogvliet eigenzinnige stad. Investeringsplan Strategische Wijkaanpak Hoogvliet-Noord en Maasranden [Hoogvliet Self-Willed City. Investment Plan Strategic Neighbourhood Approach \& Maasranden]. Rotterdam, Deelgemeente Hoogvliet.

Dijkhoff, T., 2014. The Dutch Social Support Act in the shadow of the decentralization dream. Journal of Social Welfare and Family Law, 36(3), 276-294.

Egan, M., Katikireddi, S. V., Kearns, A., Tannahill, C., Kalacs, M., \& Bond, L., 2013. Health effects of neighborhood demolition and housing improvement: a prospective controlled study of 2 natural experiments in urban renewal. American Journal of Public Health, 103 (6), e47-e53.

Ekström, M., 1994. Elderly people's experiences of housing renewal and forced relocation: Social theories and contextual analysis in explanations of emotional experiences. Housing Studies, 9 (3), 369-391.

Fried, M., 1963. Grieving for a lost home: psychological costs of relocation. In L. Duhl (Ed.), The Urban Condition (pp. 151-171). New York, Basic Books.

Gardner, P. J., 2011. Natural neighborhood networks - Important social networks in the lives of older adults aging in place. Journal of Aging Studies, 25 (3), 263-271.

Gavrilov, L., \& Heuveline, P., 2003. Aging of Population: The Encyclopedia of Population. New York, MacMillan.

Gilroy, R., 2008. Places that support human flourishing: lessons from later life. Planning Theory \& Practice, 9 (2), 145-163.

Goetz, E. G., 2010. Desegregation in 3D: displacement, dispersal and development in American public housing. Housing Studies, 25 (2), 137-158.

Greenbaum, S., Hathaway, W., Rodriguez, C., Spalding, A., \& Ward, B., 2008. Deconcentration and Social Capital: Contradictions of a Poverty Alleviation Policy. Journal of Poverty, 12 (2), 201-228.

Hardill, I., \& Baines, S., 2009. Active Citizenship in Later Life: Older Volunteers in a Deprived Community in England. The Professional Geographer, 61(1), 36-45.

Jacobs, D. E., Brown, M. J., Baeder, A., Sucosky, M. S., Margolis, S., Hershovitz, J. \& Morley, R. L., 2010. A systematic review of housing interventions and health: introduction, methods, and summary findings. Journal of Public Health Management and Practice, 16 (5), S5-S10.

Jones, P., \& Evans, J., 2012. Rescue Geography: Place Making, Affect and Regeneration. Urban studies, 49 (11), 2315-2330.

Kearns, A., \& Mason, P., 2013. Defining and measuring displacement: is relocation from restructured neighbourhoods always unwelcome and disruptive? Housing Studies, 28 (2), 177-204.

Kearns, A., Whitley, E., Tannahill, C., \& Ellaway, A., 2014. Loneliness, social relations and health and well-being in deprived communities. Psychology, Health \& Medicine (ahead-of-print), 1-13.

Kleinhans, R., 2003. Displaced but still moving upwards in the housing career? Implications of forced residential relocation in the Netherlands. Housing Studies, 18 (4), 473-499. 
Kleinhans, R., 2012. A Glass Half Empty or Half Full? On the Perceived Gap between Urban Geography Research and Dutch Urban Restructuring Policy. International Journal of Housing Policy, 12 (3), 299-314.

Kleinhans, R., \& Veldboer, L., 2012. Fighting a losing battle? Neighbourhood-based social mobility in times of retrenching social interventions. Paper presented at the 2012 ENHR Conference 'Housing: Local Welfare and Local Markets in a Globalised World', Oslo.

Kleinhans, R., Veldboer, L., Doff, W., Jansen, S., \& Van Ham, M., 2014. Terugblikken en vooruitkijken in Hoogvliet: 15 jaar stedelijke vernieuwing en de effecten op wonen, leefbaarheid en sociale mobiliteit. Delft, Delft University of Technology, Faculty of Archicture \& the Built Environment.

Lager, D., Van Hoven, B., \& Huigen, P., 2013. Dealing with change in old age: Negotiating working-class belonging in a neighbourhood in the process of urban renewal in the Netherlands. Geoforum, 50, 54-61.

Laerd Statistics, 2014. McNemar's test using SPSS. Availabe on: https://statistics.laerd.com/spss-tutorials/mcnemars-test-using-spss-statistics.php, accessed on October 23 ${ }^{\text {rd }}, 2014$.

Lindberg, R. A., Shenassa, E. D., Acevedo-Garcia, D., Popkin, S. J., Villaveces, A., \& Morley, R. L., 2010. Housing interventions at the neighborhood level and health: a review of the evidence. Journal of Public Health Management and Practice, 16 (5), S44-S52.

Lui, C. W., Everingham, J. A., Warburton, J., Cuthill, M., \& Bartlett, H., 2009. What makes a community age-friendly: A review of international literature. Australasian Journal on Ageing, 28 (3), 116-121.

Manley, D., Ham, M. van, Bailey, N., Simpson, L. and Maclennan, D. (Eds.), 2013. Neighbourhood Effects or Neighbourhood Based Problems? A Policy Context. Dordrecht, the Netherlands, Springer.

Manzo, L. C., 2014. On uncertain ground: being at home in the context of public housing redevelopment. International Journal of Housing Policy (ahead-of-print), 1-22.

Manzo, L. C., Kleit, R. G., \& Couch, D., 2008. "Moving Three Times Is Like Having Your House on Fire Once": The Experience of Place and Impending Displacement among Public Housing Residents. Urban studies, 45 (9), 1855-1878.

ODPM, 2006. UK Presidency EU ministerial informal on sustainable communities: European evidence review papers. London, Office of the Deputy Prime Minister.

Phillips, D., Siu, O., Yeh, A., \& Cheng, K., 2005. Ageing and the urban environment. In: Andrews, D. (Ed.), Ageing and place: Perspectives, Policy, Practice. New York, Routledge, pp. 147-163.

Phillipson, C., 2011. Developing age-friendly communities: New approaches to growing old in urban environments. In: Settersten, J.A. (Ed.), Handbook of Sociology of Aging. New York, Springer, pp. 279-293.

Posthumus, H., Bolt, G., \& Van Kempen, R., 2014. Victims or victors? The effects of forced relocations on housing satisfaction in Dutch cities. Journal of Urban Affairs, 36 (1), 13-32.

Priemus, H., Kemp, P. A., \& Varady, D. P., 2005. Housing vouchers in the United States, Great Britain, and the Netherlands: Current issues and future perspectives. Housing Policy Debate, 16 (3-4), 575-609.

Rowles, G., \& Watkins, J., 2003. History, Habit, Heart, and Hearth: On Making Spaces into Places. In: Warner Schaie, K., Wahl, H., Mollenkopf, H. \& Oswald, F. (Eds.) Aging Independently: Living Arrangements and Mobility. New York, Springer Publishing Company, pp. 77-96.

Scharf, T., \& de Jong Gierveld, J., 2008. Loneliness in urban neighbourhoods: an Anglo- 
Dutch comparison. European Journal of Ageing, 5 (2), 103-115.

Sixsmith, J., Sixsmith, A., Fänge, A. M., Naumann, D., Kucsera, C., Tomsone, S., Woolrych, R., 2014. Healthy ageing and home: The perspectives of very old people in five European countries. Social Science \& Medicine, 106, 1-9.

Smith, A. E., 2009. Ageing in urban neighbourhoods: Place attachment and social exclusion. Bristol, Policy Press.

Soede, A., 2012. Tevreden met pensioen. The Hague, Social and Cultural Planning Office.

Thomson, H., Atkinson, R., Petticrew, M., \& Kearns, A., 2006. Do urban regeneration programmes improve public health and reduce health inequalities? A synthesis of the evidence from UK policy and practice (1980-2004). Journal of Epidemiology and Community Health, 60 (2), 108-115.

Thomson, H., Thomas, S., Sellstrom, E., \& Petticrew, M., 2009. The health impacts of housing improvement: a systematic review of intervention studies from 1887 to 2007. American Journal of Public Health, 99 (S3).

Tinker, A., Ginn, J., \& Ribe, E., 2013. Assisted Living Platform - The Long Term Care Revolution: A study of innovatory models to support older people with disabilities in the Netherlands. Housing Learning and Improvement Network (LIN) Casestudy 37, London.

Van Der Meer, M., Fortuijn, J. D., \& Thissen, F., 2008. Vulnerability and environ-mental stress of older adults in deprived neighbourhoods in the Netherlands. Tijdschrift voor economische en sociale geografie, 99 (1), 53-64.

Van Ginneken, E., Busse, R., \& Gericke, C. A., 2008. Universal private health insurance in the Netherlands: The first year. Journal of Management \& Marketing in Healthcare, 1 (2), 139-153.

Veldboer, L., Duyvendak, J., Kleinhans, R., \& Boonstra, N., 2007. In beweging brengen en richting geven. Herstructurering en sociale stijging in Hoogvliet. Rotterdam, Deelgemeente Hoogvliet.

Veldboer, L., 2010. Afstand en betrokkenheid in de gemengde wijk (PhD thesis). Amsterdam, Off Page.

WHO, 2007. Global age-friendly cities: A guide. Geneva, World Health Organization.

Wiles, J., 2005. Home as a new site of care provision and consumption. In: Andrews, G.J. \& . Phillips, D.R. (Eds.) Ageing and Place; Perspectives, Policy, Practice. New York, Routledge, pp. 79-97.

Wiles, J., Leibing, A., Guberman, N., Reeve, J., \& Allen, R., 2012. The meaning of "aging in place" to older people. Gerontologist, 52(3), 357-366.

Wilson, I., 2013. Outcomes for 'stayers' in urban regeneration areas: the New Deal for Communities Programme in England. Urban Research \& Practice, 6 (2), 174-193.

Ziegler, F., 2012. "You have to engage with life, or life will go away": An intersectional life course analysis of older women's social participation in a disadvantaged urban area. Geoforum, 43 (6), 1296-1305.

Zwaard, J. van de \& Wilde, J. de, 2008. Thuis in de nieuwe wijk. Woonbeleving en wijkbetrokkenheid van herstructurering-uitverhuizers. Rotterdam, CMO Stimulans. 
Appendix A Personal characteristics $(\mathbf{n}=160)$

\begin{tabular}{lrr}
\hline Indicator & $\mathbf{n}$ & \% \\
\hline Sex: & & \\
- Male & 107 & 66.9 \\
- Female & 53 & 33.1 \\
Age: & & \\
$63-74$ & 76 & 47.5 \\
$75-84$ & 71 & 44.4 \\
85 and older & 13 & 8.1 \\
Household composition: & & \\
- Single & 60 & 37.5 \\
- Couple without kids & 90 & 56.3 \\
- Couple with kids & 7 & 4.4 \\
- Other & 3 & 1.9 \\
Education: & & \\
- Primary school (or less) & 43 & 26.9 \\
- Lower secondary education & 60 & 37.5 \\
- Lower professional education & 23 & 14.4 \\
- Higher secondary education & 5 & 3.1 \\
- Higher professional education & 10 & 6.3 \\
- Other & 19 & 11.9 \\
Country of birth: & & \\
- The Netherlands & 144 & 90.0 \\
- Surinam & 6 & 3.8 \\
- Indonesia/Molukken & 7 & 4.4 \\
- Other & 3 & 1.9 \\
\hline
\end{tabular}

